\title{
MUSCULOSKELETAL DISCOMFORT IN PRODUCTION ASSEMBLY WORKERS
}

\author{
Kristjan Jansen ${ }^{1}$, Matis Luik ${ }^{2}$, Märt Reinvee ${ }^{2}$, Viljo Viljasoo ${ }^{2}$, \\ Jaan Ereline ${ }^{1}$, Helena Gapeyeva ${ }^{1}$, Mati PäÄsuke ${ }^{1}$ \\ ${ }^{1}$ Institute of Exercise Biology and Physiotherapy, University of Tartu, Tartu, Estonia \\ ${ }^{2}$ Institute of Technology, Estonian University of Life Sciences, Tartu, Estonia
}

\begin{abstract}
The purpose of this study was to analyse subjective self-evaluation of musculoskeletal discomfort conducted by female production assembly workers. Thirty-seven female assembly workers aged 20-54 years participated in this study, whereas 35 of them were right-handed. Discomfort in neck, shoulder, upper back, upper arm, low back, forearm, wrist, hips, thigh, knees, lower legs and heels was subjectively evaluated by Cornell Musculoskeletal Discomfort Questionnaire. The results indicated that female assembly workers felt most work-related discomfort in the neck (44\%), lower back (19.7\%) and in the right wrist $(15 \%)$. Discomfort was less pronounced in the right knee $(0.01 \%)$, left upper arm (0.04\%) and left hip buttocks $(0.1 \%)$. In conclusion, this study indicated that subjective discomfort sensed by female production assembly workers was higher in the neck, lower back, right shoulder and the right wrist. According to the study results, further research is needed on the relationship between musculoskeletal discomfort and its influence on the quality of assembly work.
\end{abstract}

Keywords: physical workload, discomfort, pain

\section{INTRODUCTION}

Global competition in the manufacturing sector has created an environment for continuous improvement, resulting in developing methods to increase capacity while lowering costs. One way for attaining the latter is re-organizing the production by using more effective equipment together with established production practices, e.g. Lean manufacturing or different ISO management standards. Being competitive includes not only the re-organization of production but 
also paying more attention to the workforce, more specifically the employees' state of health.

In the manufacturing industry the work movements are repetitive and work situations often cause pain in the neck-arm region. These repetitive movements can be pushing, pulling, drawing, reaching, turning, raising, gripping or hitting and most of all this concerns professions such as painter, decorator, riveter, pneumatic tools operator and user of desktop computer [7].

Many occupations require workers to stand for prolonged periods, which can cause both discomfort and pain. Analytical results have demonstrated that the floor type and the work time spent standing significantly affected subjective ratings for leg discomfort and circumferential shank measurements in both laboratory and field studies. Besides, having suitable footwear also significantly affected the employees' subjective ratings for leg discomfort. It can be concluded that footwear and floor conditions and prolonged standing influence workers' lower extremity discomfort. These analytical findings suggest that common ergonomic interventions, e.g. modifying the flooring on which workers stand might alleviate leg edema for workers standing for $4 \mathrm{~h}$-shifts in laboratory and field settings. Nevertheless, prolonged standing for even $1 \mathrm{~h}$ without rest showed negative effects and should be avoided when possible [10].

The development of work-related musculoskeletal disorders does not involve only work situations and physical factors, the psychosocial factors are equally important. The work of Eatough et al. [2] supports the notion that psychosocial stressors in work environment have important links to employee health, especially work-related musculoskeletal disorder symptoms. Furthermore, Giuliano and Leonardo [5] described in their study that already Bernardino Ramazzini (1633-1714) recognized the need to undertake measures to prevent disorders from repetitive motions and manual lifting and anticipated the now widely accepted advice of moderation and recommendations of reduction of work duration for a number of hard jobs requiring a standing position or severe muscular effort. From his early writings it is evident that Ramazzini acknowledged the importance of assessing the ergonomic factors associated with the occurrence of work-related musculoskeletal disorders.

The purpose of this study was to analyse musculoskeletal discomfort in production workers at a manufacturing plant and to use these data in the risk assessment of the factory as a preventive action to maintain workers' working ability for a longer period of time. 


\section{MATERIALS AND METHODS}

\section{Subjects}

Thirty-seven females, working as assembly workers, aged from 22 to 54 years (with mean \pm SE age: $36.4 \pm 10.4$ years) participated in this study. The mean $( \pm S E)$ height, body mass and body mass index of the subjects were $166.8 \pm 4.2 \mathrm{~cm}, 61.0 \pm 9.5 \mathrm{~kg}$ and $21.9 \pm 3.7 \mathrm{~kg} / \mathrm{m}^{2}$, respectively and their general employment stage as manufacturing worker was $7.35 \pm 5.5$ years. Thirty-five workers were right-handed.

The subjects participated in the research voluntarily and the selection of manufacturing workers was random. In the chosen factory was implemented the Lean manufacturing production practice together with a number of ergonomically designed work places. The production process was organized in two shifts. During the 8-hour working day there were two short 10-min breaks for recovery and one 30-min break for lunch. The subjects were familiarized with the essence and the aims of the survey.

\section{Measures}

Cornell Musculoskeletal Discomfort Questionnaire (CMDQ) was used in this study. The CMDQ is a 54-item questionnaire containing a body mapdiagram and questions about the prevalence of musculoskeletal ache, pain or discomfort in 18 regions of the body during the previous week (Figure 1). Test-retest reliability for CMDQ at a 3-week interval found a 7\% difference in responses for upper body parts and a $1 \%$ difference for lower body parts [6]. Respondents indicated the frequency of discomfort on an ordinal scale from 0 (none) to 4 (daily) and severity of discomfort from 1 (slightly uncomfortable) to 3 (very uncomfortable). A pain level of at least "moderately uncomfortable" was selected as a severity threshold for determining prevalence and frequency. The level at which the discomfort interferred with work was scored from 0 (no interference) to 2 (substantial interference). Total discomfort score was calculated by using the following formula: frequency $x$ discomfort $x$ interference $=$ discomfort score.

The questionnaires were filled in at the workplace. The subjects wrote the values of height and body weight themselves and the body mass index $\left(\mathrm{kg} / \mathrm{m}^{2}\right)$ was calculated.

For the most part of the workday assembly workers sit on a chair or stand behind their working desk, driving screws into the aluminium plate with pneumatic screwdriver (Figure 2). It is important to emphasize that the torque level of pneumatic screwdriver was not recorded. 


\begin{tabular}{|c|c|c|c|c|c|c|c|c|c|c|c|c|c|}
\hline \multicolumn{3}{|c|}{$\begin{array}{l}\text { The diagram below shows the approximate } \\
\text { position of the body parts referred to in the } \\
\text { questionnaire. Please answer by marking } \\
\text { the appropriate box. }\end{array}$} & \multicolumn{5}{|c|}{$\begin{array}{l}\text { During the last work week } \\
\text { how often did you experience } \\
\text { ache, pain, discomfort in: }\end{array}$} & \multicolumn{3}{|c|}{$\begin{array}{l}\text { If you experienced ache, pain, } \\
\text { discomfort, how uncomfortable } \\
\text { was this? }\end{array}$} & \multicolumn{3}{|c|}{$\begin{array}{l}\text { If you experienced ache, } \\
\text { pain, discomfort, did } \\
\text { this interfere with your } \\
\text { ability to work? }\end{array}$} \\
\hline & \multirow{2}{*}{\multicolumn{2}{|c|}{ Neck }} & Neve & $\begin{array}{l}1-2 \\
\text { times } \\
\text { hist } \\
\text { week }\end{array}$ & $\begin{array}{l}34 \\
\text { times } \\
\text { last } \\
\text { week }\end{array}$ & $\begin{array}{c}\text { Oncee } \\
\text { every } \\
\text { dayy }\end{array}$ & $\begin{array}{l}\text { Several } \\
\text { times } \\
\text { evey } \\
\text { day }\end{array}$ & \begin{tabular}{|l} 
Slightly \\
uncomfortabl
\end{tabular} & \multicolumn{2}{|c|}{$\begin{array}{l}\text { Moderately Very } \\
\text { ble uncomfortable uncomfortable }\end{array}$} & \multirow{2}{*}{$\begin{array}{c}\text { Notat all } \\
\square\end{array}$} & \multirow{2}{*}{$\begin{array}{c}\begin{array}{c}\text { Slinghly } \\
\text { interfere }\end{array} \\
\square\end{array}$} & \multirow{2}{*}{$\begin{array}{c}\begin{array}{c}\text { Substantially } \\
\text { ineffred }\end{array} \\
\square \\
\square\end{array}$} \\
\hline & & & $\square$ & $\square$ & $\square$ & $\square$ & $\square$ & $\square$ & $\square$ & $\square$ & & & \\
\hline & Shoulder & $\begin{array}{l}\text { (Right) } \\
\text { (Left) }\end{array}$ & $\begin{array}{l}\square \\
\square\end{array}$ & $\begin{array}{l}\square \\
\square\end{array}$ & $\begin{array}{l}\square \\
\square\end{array}$ & $\begin{array}{l}\square \\
\square\end{array}$ & $\begin{array}{l}\text { ㅁ } \\
\square\end{array}$ & 믐 & 믐 & 믐 & 뭄 & $\begin{array}{l}\text { ㅁ } \\
\square\end{array}$ & 믐 \\
\hline & Upper Back & & $\square$ & $\square$ & $\square$ & $\square$ & $\square$ & $\square$ & $\square$ & $\square$ & $\square$ & $\square$ & $\square$ \\
\hline & Upper Arm & $\begin{array}{l}\text { (Right) } \\
\text { (Left) }\end{array}$ & $\begin{array}{l}\square \\
\square\end{array}$ & $\begin{array}{l}\square \\
\square\end{array}$ & $\begin{array}{l}\square \\
\square\end{array}$ & $\begin{array}{l}\square \\
\square\end{array}$ & $\begin{array}{l}\square \\
\square\end{array}$ & $\begin{array}{l}\square \\
\square\end{array}$ & $\begin{array}{l}\square \\
\square\end{array}$ & $\begin{array}{l}\square \\
\square\end{array}$ & $\begin{array}{l}\square \\
\square\end{array}$ & $\begin{array}{l}\square \\
\square\end{array}$ & $\begin{array}{l}\square \\
\square\end{array}$ \\
\hline & Lower Back & & $\square$ & $\square$ & $\square$ & $\square$ & 口 & $\square$ & $\square$ & $\square$ & $\square$ & 口 & ㅁ \\
\hline & Forearm & $\begin{array}{l}\text { (Right) } \\
\text { (Left) }\end{array}$ & $\begin{array}{l}\square \\
\square\end{array}$ & $\begin{array}{l}\square \\
\square\end{array}$ & $\begin{array}{l}\square \\
\square\end{array}$ & $\begin{array}{l}\square \\
\square\end{array}$ & $\begin{array}{l}\square \\
\square\end{array}$ & $\begin{array}{l}\square \\
\square\end{array}$ & $\begin{array}{l}\square \\
\square\end{array}$ & $\begin{array}{l}\square \\
\square\end{array}$ & $\begin{array}{l}\square \\
\square\end{array}$ & $\begin{array}{l}\square \\
\square\end{array}$ & $\begin{array}{l}\square \\
\square\end{array}$ \\
\hline & Wrist & $\begin{array}{l}\text { (Right) } \\
\text { (Left) }\end{array}$ & $\begin{array}{l}\square \\
\square\end{array}$ & $\begin{array}{l}\square \\
\square\end{array}$ & $\begin{array}{l}\square \\
\square\end{array}$ & $\begin{array}{l}\square \\
\square\end{array}$ & $\begin{array}{l}\square \\
\square\end{array}$ & $\begin{array}{l}\square \\
\square\end{array}$ & $\begin{array}{l}\square \\
\square\end{array}$ & $\begin{array}{l}\square \\
\square\end{array}$ & $\begin{array}{l}\square \\
\square\end{array}$ & $\begin{array}{l}\square \\
\square\end{array}$ & $\begin{array}{l}\square \\
\square\end{array}$ \\
\hline & Hip/Buttock & & $\square$ & $\square$ & $\square$ & $\square$ & $\square$ & $\square$ & $\square$ & $\square$ & $\square$ & $\square$ & $\square$ \\
\hline & Thigh & $\begin{array}{l}\text { (Right) } \\
\text { (Left) }\end{array}$ & $\begin{array}{l}\square \\
\square\end{array}$ & $\begin{array}{l}\text { ㅁ } \\
\square\end{array}$ & $\begin{array}{l}\square \\
\square\end{array}$ & $\begin{array}{l}\square \\
\square\end{array}$ & $\begin{array}{l}\text { 뭄 } \\
\end{array}$ & 믐 & $\begin{array}{l}\text { 문 } \\
\square\end{array}$ & 믐 & $\begin{array}{l}\text { ㅁ } \\
\square\end{array}$ & 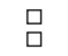 & 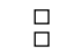 \\
\hline & Knee & $\begin{array}{l}\text { (Right) } \\
\text { (Left) }\end{array}$ & $\begin{array}{l}\square \\
\square\end{array}$ & $\begin{array}{l}\square \\
\square\end{array}$ & $\begin{array}{l}\square \\
\square\end{array}$ & $\begin{array}{l}\square \\
\square\end{array}$ & $\begin{array}{l}\text { 뭄 } \\
\end{array}$ & 믐 & $\begin{array}{l}\square \\
\square\end{array}$ & 믐 & 믐 & 믐 & 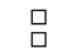 \\
\hline & Lower Leg & $\begin{array}{l}\text { (Right) } \\
\text { (Left) }\end{array}$ & $\begin{array}{l}\square \\
\square\end{array}$ & $\begin{array}{l}\square \\
\square\end{array}$ & $\begin{array}{l}\square \\
\square\end{array}$ & $\begin{array}{l}\square \\
\square\end{array}$ & 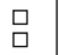 & $\begin{array}{l}\square \\
\square\end{array}$ & 믐 & $\begin{array}{l}\text { ㅁ } \\
\square\end{array}$ & 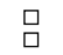 & $\begin{array}{l}\text { ㅁ } \\
\square\end{array}$ & $\begin{array}{l}\text { 뭄 } \\
\text { a }\end{array}$ \\
\hline Comellliniersid, 2003 & Foot & $\begin{array}{l}\text { (Right) } \\
\text { (Left) }\end{array}$ & $\begin{array}{l}\square \\
\square\end{array}$ & $\begin{array}{l}\square \\
\square\end{array}$ & $\begin{array}{l}\square \\
\square\end{array}$ & $\begin{array}{l}\square \\
\square\end{array}$ & $\begin{array}{l}\square \\
\square\end{array}$ & $\begin{array}{l}\square \\
\square\end{array}$ & $\begin{array}{l}\square \\
\square\end{array}$ & $\begin{array}{l}\square \\
\square\end{array}$ & $\begin{array}{l}\square \\
\square\end{array}$ & $\begin{array}{l}\square \\
\square\end{array}$ & $\begin{array}{l}\square \\
\square\end{array}$ \\
\hline
\end{tabular}

Figure 1. Cornell musculoskeletal discomfort questionnaire, female version. (Reproduced with permission from the Human Factors and Ergonomics Laboratory at Cornell University). (http://ergo.human.cornell.edu/ahmsquest.html).

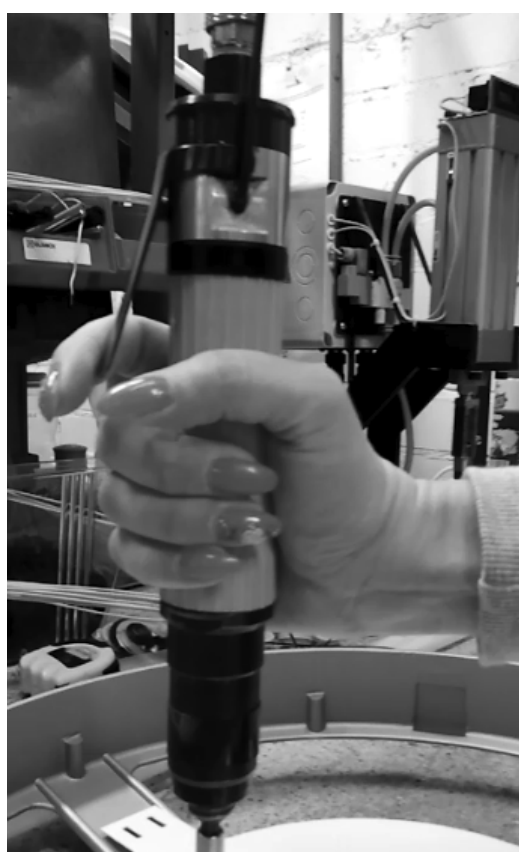




\section{Statistical analyses}

When processing the data, the standard statistical methods were used for calculating the mean and the standard error $( \pm \mathrm{SE})$.

\section{RESULTS}

Seventy-three percent of the subjects experienced discomfort at or above the moderate severity level in at least one body region in the 7 days prior to questionnaire completion (Table 1). According to the total discomfort score of CMDQ (Table 2), it was concluded that female assembly workers felt discomfort mostly in the neck (44\%), lower back (19.7\%) and the right wrist (15\%), while it was less pronounced in the right knee $(0.01 \%)$, left upper arm $(0,04 \%)$ and left hip buttocks (0.1\%).

More specifically, the results indicated that 21 (56.7\%) workers sensed discomfort in the neck 1-2 times per week or more and 14 of them assessed that this discomfort had a minor effect on their ability to work. Seventeen (46\%) workers assessed low back discomfort 1-2 times per week or more and because of this discomfort, 10 (27\%) workers estimated that this had a minor effect on their ability to work. The right wrist of production assembly workers was more loaded than other body regions; 14 (37.8\%) workers felt discomfort there 1-2 times per week or more and 10 of them sensed that this had a minor effect on their work performance. 
Musculoskeletal discomfort in production assembly workers | 107

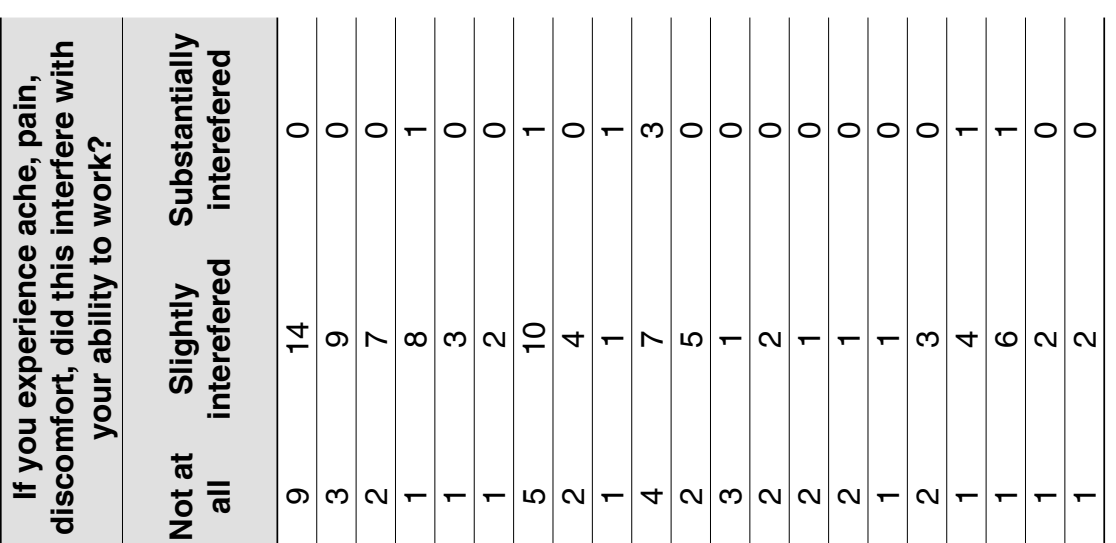

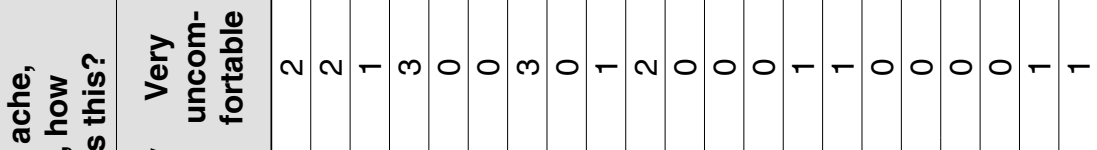

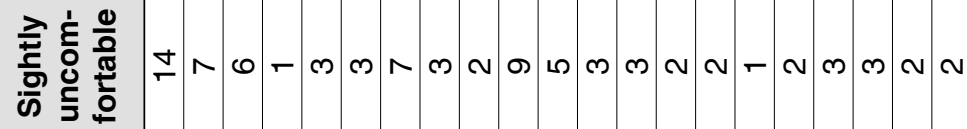

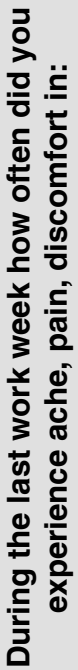
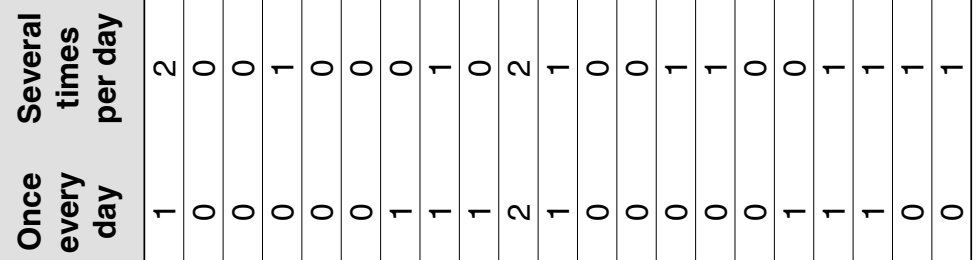

m

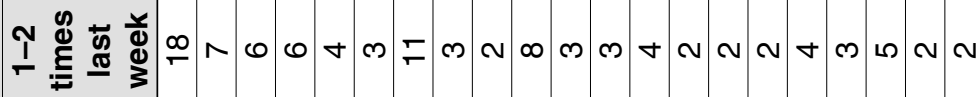
¿্য $\frac{\infty}{0}$
$\frac{0}{0}$
$\frac{0}{2}$
$\frac{0}{0}$
$\frac{0}{0}$
$\frac{0}{10}$

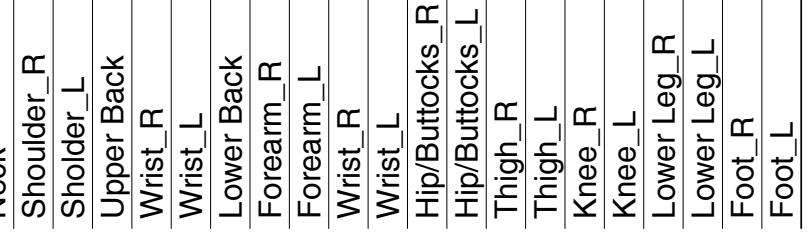


Table 2. Total discomfort score

\begin{tabular}{lccccc}
\hline $\begin{array}{l}\text { Body parts } \\
\text { referred to in the } \\
\text { questionnaire }\end{array}$ & $\begin{array}{c}\text { Fre- } \\
\text { quency }\end{array}$ & $\begin{array}{c}\text { Dis- } \\
\text { comfort }\end{array}$ & $\begin{array}{c}\text { Inter- } \\
\text { ference }\end{array}$ & $\begin{array}{c}\text { Discomfort } \\
\text { score }\end{array}$ & $\%$ \\
\hline Neck & 59 & 36 & 38 & 80712 & 43.89 \\
\hline Lower Back & 44.5 & 29 & 28 & 36134 & 19.65 \\
\hline Wrist_R & 48.5 & 21 & 27 & 27500 & 14.95 \\
\hline Upper Back & 22.5 & 22 & 20 & 9900 & 5.38 \\
\hline Shoulder_R & 24.5 & 19 & 20 & 9310 & 5.06 \\
\hline Lower Leg_L & 26 & 13 & 16 & 5408 & 2.94 \\
\hline Shoulder_L & 16 & 15 & 16 & 3840 & 2.09 \\
\hline Forearm_R & 23 & 15 & 11 & 3795 & 2.06 \\
\hline LowerLeg_R & 23 & 9 & 12 & 2484 & 1.35 \\
\hline Wrist_L & 16.5 & 9 & 12 & 1782 & 0.97 \\
\hline Knee_L & 11 & 8 & 8 & 704 & 0.38 \\
\hline Forearm_L & 13 & 6 & 6 & 468 & 0.25 \\
\hline Foot_R & 13 & 5 & 5 & 325 & 0.18 \\
\hline Foot_L & 13 & 5 & 5 & 325 & 0.18 \\
\hline Thigh_R & 13 & 5 & 4 & 260 & 0.14 \\
\hline Thigh_L & 13 & 5 & 4 & 260 & 0.14 \\
\hline Upper Arm_R & 6 & 5 & 7 & 210 & 0.11 \\
\hline Hip/Buttocks_R & 8 & 5 & 5 & 200 & 0.11 \\
\hline Hip/Buttocks_L & 6 & 5 & 6 & 180 & 0.10 \\
\hline Upper Arm_L & 4.5 & 3 & 5 & 68 & 0.04 \\
\hline Knee_R & 3 & 3 & 3 & 27 & 0.01 \\
\hline & & & & & \\
\hline
\end{tabular}

\section{DISCUSSION}

Several studies have shown similar results to the present study. For example, the physical assessment of 146 female workers in highly repetitive jobs found $54 \%$ to have musculoskeletal disorders in the upper limb that were potentially work-related [8]. Many workers had multiple problems, and/or were affected bilaterally (33\% of workers). Muscle pain and tenderness was the largest problem, both in the neck/shoulder area (31\%) as expected and in the forearm/ hand musculature (23\%), a previously unreported site [8].

In the study where relationships between a number of ergonomic conditions and product quality in car assembly plant were examined, the results showed that quality deficiencies were three times as common for the work tasks with ergonomics problems, compared with other tasks and an increased 
risk of quality deficiencies was established for all three categories of ergonomic problems investigated [3]. Direct causes of quality deficiencies were identified, such as discomfort from strained parts of the body, organizational factors and time pressure. The analysis pointed to certain types of tasks that were more likely than others to cause quality problems. The results also showed that an important factor for job satisfaction for the workers was the possibility to perform their tasks with high quality. The study therefore confirms close relationships between ergonomics and quality [3]. Singh et al. [9] found in their study that ergonomically designed equipment reduced physiological and economic costs over others. In another study Dianat et al. [1] investigated the effects of wearing typical industrial gloves on hand performance capabilities (muscle activity, wrist position, touch sensitivity, hand grip and forearm torque strength) and subjective assessments for an extended duration of performing a common assembly task - wire tying with pliers - requiring a combination of manipulation and force exertion. The results showed that wearing gloves significantly increased muscle activity, wrist deviation, and discomfort whilst reducing hand grip strength, forearm torque strength and touch sensitivity.

The causes of cumulative trauma disorders are complex in nature and usually no single factor or simple reason can be determined during work evaluation. Cumulative trauma disorders, also called repetitive strain injuries, have been found to be a major source of occupational disability; their causes and contributing events need to be carefully studied [4].

In conclusion, this study indicated that the feeling of discomfort, subjectively felt by female production assembly workers was higher in the neck, lower back, right shoulder and the right wrist. Further research is needed on the relationship between musculoskeletal discomfort and its influence on the quality of assembly work.

\section{REFERENCES}

1. Dianat I, Haslegrave CM, Stedmon A. (2012) Using pliers in assembly work: Short and long task duration effects of gloves on hand performance capabilities and subjective assessments of discomfort and ease of tool manipulation. App Ergon, 43: 413-423

2. Eatough EM, Way JD, Chang C. (2012) Understanding the link between psychosocial work stressors and work-related musculoskeletal complaints. App Ergon, 43: 554-563

3. Eklund J. (1995) Relationships between ergonomics and quality in assembly work. App Ergon, 26: 15-20

4. Gilad I. (1995) A methodology for functional ergonomics in repetitive work. Ind Ergon, 15: 91-101 
5. Giuliano F, Leonardo F. (2003) Bernardino Ramazzini's early observations of the link between musculoskeletal disorders and ergonomic factors. App Ergon, 35: $67-70$

6. Hedge A, Morimoto S, McCrobie D. (1999) Effects of keyboard tray geometry on upper body posture and comfort. Ergon, 42: 1333-1349

7. Hughes P, Ferrett E. (2003) Introduction to Health and Safety at Work. The Handbook for the NEBOSH National General Certificate. Physical and Psychological Health Hazards and Control, Oxford

8. Ranney D, Wells R, Moore A. (1995) Upper limb musculoskeletal disorders in highly repetitive industries: precise anatomical physical findings. Ergon, 38: 1408-1423

9. Singh SP, Singh S, Singh P. (2012) Ergonomics in developing hand operated maize dehusker-sheller for farm women. App Ergon, 43: 792-798

10. Yen-Hui L, Chih-Yong C, Min-Hsien C. (2012) Influence of shoe/floor conditions on lower leg circumference and subjective discomfort during prolonged standing. App Ergon, 43: 965-970

\section{Correspondence to:}

Kristjan Jansen

Institute of Exercise Biology and Physiotherapy

Faculty of Exercise and Sport Sciences

University of Tartu

Jakobi 5, Tartu 51014

Estonia

E-mail:jansen@ut.ee 